\title{
Social perception of the integration of Romani people (Gypsies) into the labor market
}

\author{
Lect. Univ. dr. Mihaela Luminița Sandu \\ "Ovidius" University of Constanta, Romania \\ mihaela_naidin@yahoo.com \\ Prof. univ. dr. habil. Mihaela Rus \\ "Ovidius" University of Constanta, Romania \\ psiholog_m@yahoo.com
}

Lect. univ. dr. Ciprian Vasile Rus

"Ovidius" University of Constanta, Romania

\begin{abstract}
Over the years, the gypsies have been the subject of various discussions, being cataloged as „dirty gypsies, thieves, lazy and who do not want to learn” and especially those responsible for the negative image of Romania abroad, in other words they were "the apple of discord” in the Romanian society. The „valves” were also opened after the incidents in France in 2010 that generated new discussions on the problems due to the Roma, the optimal solution in solving these problems being the integration of the Roma in the society. However, the vast majority of Romanians are reluctant to integrate the gypsies into society, especially on the labor market, and this is due to the public image, most often negative, which gypsies "enjoy". We chose this theme, in the idea of supporting the integration of the Roma in the labor market, considering this step an advantage in favor of the economy of the country, since the limited access of Roma people to the labor market causes Romania to lose at least 887 million euros annually, according to a report by the World Bank. Also, we consider it is necessary to integrate them in the labor market and due to the fact that the taxes and social contributions that they pay are far below the majority population, with notable effects on the Gross Domestic Product. A final argument that contributed to the choice of this theme is that the integration of the members of this population in the labor market could be a positive proof for the efficiency of the policies and projects implemented over time in their favor.
\end{abstract}

Keywords. perception, integration, gypsies, work

\section{Gypsy minority}

"Gypsy problem" (Stoian, Mark et al, 2010) is a topic well known to all. It is known and affirmed by government representatives in many of the debates, symposia, conferences, organized for decades. Until recently it was considered a serious ,problem” and the terminology used by this minority to self-identify, which results from the disagreement with the proposal of the Romanian deputy Silviu Prigoană to replace the official name of the Romani people from „rrom” in ,gypsy”, registered at the Romanian Senate in September 2010. However, what is the correct term? „Romani people” or „Gypsy”?

From a scientific point of view the correct term is that of „Romani,, being ,an old word of the Roman language, always used for the designation of Romani ethnicity" (Grigore, 2009) but by the 1980s the term was very little known in Western Europe and thus the term „gypsy” 
„was used by Romani-based organizations themselves, so that those around them knew what it was about" (Liégeois, 2008).

After 1989, the term has an interesting history that reflects on the one hand the political implications of this linguistic endeavor, and on the other hand reveals the mentalities of the time. „In January 1995, the Minister of Foreign Affairs, Teodor Melescanu issued the Memorandum proposing to use the word „Gypsy” in accordance with the terms used in other European languages to avoid confusion with the name of the Romanian people" (Antoniu, 2009). Only 5 years later, in February 2000, the new Minister of Foreign Affairs, Petre Roman produced a counter-memorandum, endorsed by the Government, which recommended the use of the term „rrom” in parallel with the alternative formulas - romani/gypsies, roms/tsiganes, roma and sinti - ,in correspondence with the international organizations that use them, change due on the one hand" to the pressures of the Romani associations „but especially to the need of Romania to meet its international obligations" (Resource Center for Ethnocultural Diversity, 2004).

In time, the word ,gypsy" retained, in the Romanian collective mind and in the Romanian language, a profoundly pejorative meaning: in the proverbs - „Neither the gypsy is like the man, nor the wicked is like the tree”, „He drowned like the gypsy on the shore”, „Gypsy is Gypsy and on Easter day", in current expressions -,,Don't be gypsy!”, including in the explanatory dictionary of the Romanian language the second edition of 1998 - „epithet given to a person with bad grips", „who has bad manners; which is very touching; chalice, scratchy" (Grigore, 1992).

While most Romanians still call them ,tigani”, the British and Americans call them „gypsy”, Germans - „zigeuner”, Hungarians - „,czigány”, French - „,czigány”, Italians „zingaro”, the Portuguese - „cigano”, the Spanish people - „gitano”, terms that derive also from the Greek word ,,athinganos" with the same pejorative meaning.

According to their specific occupations, Roma citizens are classified as follows:

1. Aurarii or rudarii - they were the most numerous of the royal slaves, and as a task, they dealt with the removal of the gold from the rivers of Moldova and the Romanian Country, paying tribute some of the quantity of gold removed; in the cold season they processed wood by making pots, thus receiving the name of spoon mills, and after the 19th century, part of them worked on the manufacture of bricks, being called bricks makers.

2. Lăeşii or lăeţii - They were skilled blacksmiths making weapons and tools. Old Greeks and documents often mention them when they were called by the gentleman and boyars to make weapons or tools.

3. Căldărarii - it processes the copper making boilers and kitchenware, boilers and others.

4. Pieptănarii - they processed the bone and made combs.

5. Argintarii- they made rings and other gold and silver jewelry.

6. Ursarii - They came from the South of the Danube, gave shows with tanned bears and made small iron objects. As a way of life they were nomads, their homes being tents.

7. Geambaşii - they bought and sold horses.

8. Clopotarii - they made bells for churches.

9. Florăresele or lustragii de ghete - appeared later.

After the overthrow of the communist regime in 1989, the situation of the Romani is marked by profound changes, racial hatred, violence and discrimination being no new terms for this ethnicity, but the Romanian revolution represented for them and a special moment not only by the significant participation of the members of the Romani ethnic group at revolution, for 
example the well-known Dumitru Dincă, the revolutionary from the University Square of Bucharest, but also through its consequences.

\section{Characteristics of the labor force in the Gypsy community}

Vocational training is an important indicator of the participation of gypsies in the social and economic life of Romania. Depending on this, they can more easily integrate into the labor market and financially support the families from which they come. Estimated at $1.8-2.5$ million, the Gypsy population in Romania faces significant problems related to employment. These include low access to education, low education and increased illiteracy, lack of skills to make them competitive in the labor market, poor access to work, widespread discrimination, poor health, poor housing conditions and extreme poverty. Many of them are aware that in order to succeed in life you have to work first and foremost, but their access to the labor market is quite limited. Statistics show that, at the level of 2009, only $22.9 \%$ of the Gypsies are economically active, and of these, only $71.5 \%$ are employed in the official economy.

Just over half of the Gypsies do not have any profession or activities that do not require a prior qualification through the formalized system of professional training. Thus, the vast majority do not have any qualifications, the persons qualified in traditional professions represent approx. 3.9\%, people qualified in modern professions represent $16.1 \%$, the number of employed gypsies is approx. $22.1 \%$, employers - $0.8 \%$, and business on their own $-16.9 \%$ (Duminică, Preda, 2003).

Traditionalism and modernity have a particular specificity for the Gypsies, due to the somewhat different way in which they have gone through certain periods of economic and social foreshadowing, managing to keep some of the traditional trades almost intact, even though they have been subjected to sustained processes of adaptation to modernity.

In a continuous decline, the traditional gypsy trades are no longer important sources of subsistence, being less and less present in the younger generations. „The conditions for traditional family work are getting tougher, and the demand market for such activities and services is getting smaller" (Magyari, 2018). With the changes suffered over the years by the Romanian society, the gypsies were forced to adapt slowly by giving up the old activities, practicing new trades such as: collecting waste and reusable materials (iron, clothes, bottles, paper, etc.), the gathering of medicinal plants, berries and mushrooms, service women, carers, specific occupations for vulnerable socially and economically marginalized groups. Other activities considered as traditional such as brick, metal craft and music have a lower weight.

If the cleaning and sanitation services in the urban area represent a solution for the unqualified gypsies, in the rural area, this role belongs to agriculture $(91.5 \%$ of those active in agriculture have graduated education forms that do not provide them with formal qualifications). In agriculture, the vast majority of gypsies work as day laborers, so no systematic prior qualification is required for this profession. The relatively small share of gypsies who own land and also those who have the full experience of the land work, makes them not to be called farmers in the common sense of the word, but rather workers in the agricultural field, which implies time-consuming and high-volume work.

With regard to modern trades, some authors consider that they ,were acquired through the formal education and training system or at the workplace. The most common trades are: in constructions (masonry, painter, blacksmith-concrete worker), locksmith, car mechanic, welder, driver, tailor, in the field of services and trade, etc" (Chiriac, Constantinescu, 2007).

In close connection with work, education plays a very important role, being generally considered a key factor for the inclusion of gypsies in the Romanian society. All reference authors agree that the low level of education or the total lack of formal and vocational education are at the base of most problems of the integration of the gypsies in the labor market. 

www.techniumscience.com Gypsies do not have a job, meaning that they have not learned a job at school. The lack of financial resources of the family prevents many children from completing their studies, without them they cannot work in well-paid positions or often they cannot even commit for an indefinite period. According to a study, ,,about $80 \%$ of the unskilled employees have as a maximum level of training 8 completed classes. Most of the qualified employees $(57 \%)$ have a minimum vocational school, and the other $43 \%$ have a level of education between 4 and 8 classes" (Gheorghe, 2009). The significance of the school, the school career, with its achievements and failures, ,are all influenced by - and related to - the other realities of everyday life" (Fleck, Rughiniș, 2008)

Another feature of the gypsy workforce is the work without the employment documents. $72 \%$ of gypsies looking for a job are willing to work on the black market, regardless of conditions (Barometru de Incluziune Socială, 2010). As a result, more than half of the Gypsy employees do not have social insurance, although they are active, and only 56\% say they have health insurance, while the remaining $44 \%$ do not have health insurance. In almost $40 \%$ (Evz.ro) of the Gypsies they are employed in a private company most often, without a contract, so that only a small number of Roma employees have an indefinite contract, while most of the workers do not have any kind contract.

\section{Forms and sources of social exclusion of Roma}

„Social exclusion” is a relatively new concept, launched within the documents of the European Union and dedicated in particular by the third anti-poverty program (period 1990 1994) launched by the European Commission (Zamfir, Preda 2002). In the Romanian social space, this concept cannot be defined without analyzing the general context of transition of the Romanian society. The transition years led to an explosion of the poverty of the population in Romania, the economic growths of 2000-2007 leading to the improvement of the financial situation of the citizens, but the disaggregated processes that appeared related will heal much later. According to the sociology dictionary the term social exclusion is defined as a process by which individuals or families experience deprivation, either from resources (such as income), or from social links with a community or with society in general. In this context, at least three ways of using the term have emergedThe first of these puts social exclusion in relation to social rights and the barriers or processes by which people are prevented from exercising them. This use of the term quickly leads researchers to discussions about civil society and the modern notion of citizenship. The second way of use reveals a „Durkheimian” frame of reference ${ }^{1}$. In this case, the authors conceptualize social exclusion as a state of social or normative isolation from the rest of society, connecting it with related notions, such as anomie and through them with the problems of social integration. Finally, the term was applied to situations of extreme marginalization, especially within multicultural societies. The element that has been emphasized since then is that poverty was not only regarded as a precarious materialistic state, but was generally associated with deficiencies, including those of participation in social life, which implies more than marginalization, process that specialists call social exclusion.

A. Giddens distinguishes between people who face long-term poverty and those who go through a difficult time, or the case of the unemployed, whose social consequences are worrying for some employees who still receive some income, but where the perception of the

\footnotetext{
${ }^{1}$ Émile Durkheim, the parent of scientific sociology, said that a social fact is normal when it occurs in the middle of societies and is therefore characterized by a functional constant, regularity in production and insurance trends a relative harmony of the parts of society.
} 
states associated with them is much diminished. The author argues that „Exclusion does not refer to different degrees of inequality, but to mechanisms that act by detaching groups of people from the social environment" (Tănăsescu 2006).

After 1990, in Romania, studies on social exclusion became more and more widespread, but these became significantly larger after 2000. Thus, in 2001 the Commission on Anti-Poverty and Promotion of Social Inclusion (CASPIS) was set up, and the significant result of its activity can be found in the National Plan for Anti-Poverty and Promotion of Social Inclusion, document that is the basis for the coordination of social strategies and policies in Romania for the period 2006 - 2008.

In the paper „Roma in Romania”, Cătălin Zamfir (2002) presents a series of forms of exclusion, such as: economic exclusion and implicitly exclusion from the labor market, exclusion from education, exclusion from health services, exclusion from health services social assistance, exclusion from housing, exclusion from participation in political life, exclusion from specific opportunities in certain areas, with reference to transport or communications.

Regarding the health services, two mechanisms of exclusion of the population from the public health system have been identified:

- formal exclusion: in this category all persons who do not fulfill the conditions provided by law, in order to benefit from the public medical act, uninsured, exclusions from the health insurance system (those without identity documents, families without at least one employee, who do not was taken in the records of the institutions)

- informal exclusion which may be referred to as "exclusion of inclusions" or exclusion of insureds who meet the conditions provided by law, but who for various reasons, which concern the malfunctioning of the entire health system, specific local contexts, social, cultural or ethnic prejudices, are excluded from health services

Regarding the situation of the Roma, they fall into both types of exclusion, both formal and informal exclusion.

The main factor of the formal exclusion of the Roma is the lack of identity documents. The absence of identity documents excludes the respective person from the possibilities of exercising the majority of social rights, including the right to free healthcare or with payment facilities, because the services provided cannot be recorded in the accounting records of the providing units and therefore cannot be settled by these. The person in this situation can not even register on the list of a family doctor.

Access to housing is a basic condition for the social integration of citizens belonging to any vulnerable group as well as to fight poverty, and the lack of adequate housing is the primary way of exclusion from society and a premise to remain captive to extreme poverty.

The differences between Roma and other ethnicities deepen when we analyze the housing situation. According to the studies in the field, most of the Roma in Romania are mainly faced with problems related to the quality standard of the homes they live in, the poor infrastructure of the areas in which they live and because of the unclear legal status of their homes and land they occupy.

Regarding the quality of housing, the Roma houses are made in a higher proportion of weak materials compared to the other houses. Thus, the percentage of houses made of resistant materials (stone, brick, AAC, etc.) is much lower, with only $55 \%$ of Roma living in urban areas living in such houses. egarding the block dwelling, we observe that more than half of the Roma live in comfort blocks III / IV or in former homes of non-families. But more worrying is the dwelling in abandoned or improvised buildings - in the rural area 3\% of Roma households live in abandoned or improvised dwellings, and in the urban area their percentage reaches $8 \%$ (in the case of other ethnic groups, even if such dwellings probably exist, their number is not statistically relevant). (Bădescu et al, 2007) „But perhaps the most serious problem is the lack 
of housing security - only $66 \%$ of Roma said they live with a housing contract compared to $82 \%$ for individuals belonging to other ethnic groups. Moreover, of the Roma who have contracts about $9 \%$ live on rent (most of them in the state). Both elements mean that only 58\% of the Roma have the security of a home ownership contract compared to $81 \%$ for individuals of other ethnicities" (Bădescu et al, 2007).

However, many Roma families occupy both land and buildings illegally, either due to the lack of identity documents, which does not give them the right to access any property title, or due to permanent evictions from various other localities, evictions due to these families being forced to move from one area to another. (Cace et al, 2006). Both rural and urban, many Roma communities are located in areas where the infrastructure is either poorly developed or nonexistent - there are areas which themselves constitute an outbreak of infection, being located in areas that can hardly be rehabilitated by public authorities, precisely because of the degree of wear of the occupied lands, and the rehabilitation of the infrastructure is almost impossible. Although most of the problems faced by the Roma are also found in the non-Roma population, they also have to overcome specific obstacles for which specific measures are needed. (Cace et al, 2007)

Marian Preda defines social exclusion as „failure to fully achieve citizens' rights” (Pop, 2002). Although there are a number of excluded social groups and obvious exclusion processes in Romania, the Roma population is suffering serious processes of exclusion being likely, one of the worst affected social segments.

\section{Methodology}

On the basis that the access of the Roma population to the labour market is limited due to "barrier" factors, including discrimination, lack of schooling, and lack of professional qualification, we considered it necessary that through this study to investigate the perception of the majority population on this issue, such as Roma are perceived in the labour market.

The purpose of the present study is to analyze how the Roma population is perceived on the labor market, the importance of schooling and professional qualification from the point of view of the majority population, as well as analyze the perception of the majority population on how to integrate them into the labor market would influence the country's economy. From the point of view of the variable ,gender" tag, we observe that 43 men and 37 women participated in this study, a total of 80 subjects.

Table no. 1 Frequency of occurrence of subjects' depending on the ,gender” variable.

\begin{tabular}{|c|c|c|}
\hline & Frequency & Percent $\%$ \\
\hline Masculine & 43 & 54 \\
\hline Feminine & 37 & 46 \\
\hline Total & 80 & 100.0 \\
\hline
\end{tabular}

From a percentage point of view, the male gender represents $54 \%$, while the female gender is represented by $46 \%$ of the study participants. From the point of view of the variable "age" tag, we notice that it extends over a large range, namely 17-75 years.

Table no. 2. The frequency of occurrence of the subjects' according to the studies completed

\begin{tabular}{|c|c|c|}
\hline & Frequency & Percent \% \\
\hline No class & 0 & 0 \\
\hline Gymnasium studies & 10 & 13 \\
\hline Middle School studies & 26 & 32 \\
\hline
\end{tabular}




\begin{tabular}{|c|c|c|}
\hline Post secondary school & 2 & 3 \\
\hline Professional studies & 18 & 23 \\
\hline Superior Studies & 24 & 29 \\
\hline Total & 80 & 100.0 \\
\hline
\end{tabular}

From the point of view of the last graduated studies, following the realized study it was found that out of the 80 subjects who answered questions, only 24 of them have superior studies, 2 graduated a post-secondary school, 10 graduated from the gymnasium studies, 26 have middle school studies, the remaining of 18 are having professional studies. As a percentage, we have $32 \%$ respondents with middle school education compared to $29 \%$ individuals with superior education, $13 \%$ individuals with gymnasium studies, $3 \%$ individuals who graduated from post-secondary school and $23 \%$ respondents with professional studies.

Regarding the category of socio-demographic data, the respondents have a wide range of occupations, as follows:

Table no. 3. The frequency of occurrence of the subjects' according to occupation

\begin{tabular}{|c|c|c|c|}
\hline & & Frequency & Percent \% \\
\hline Valid & Entrepreneur / Owner & 3 & 4 \\
\hline & Housekeeper / Housewife & 7 & 9 \\
\hline & Worker & 29 & 36 \\
\hline & Retired & 8 & 10 \\
\hline & Unemployed & 3 & 4 \\
\hline & Pupil & 13 & 16 \\
\hline & Student & 10 & 13 \\
\hline & Higher education staff & 7 & 8 \\
\hline & Total & 80 & 100.0 \\
\hline
\end{tabular}

\section{Data analysis and interpretation} of people.

From the first item it can be found that work is of quite importance to the vast majority

Table no. 4. Frequency of occurrence of subjects' responses to item 1

\begin{tabular}{|l|l|c|c|}
\hline & & Frequency & Percent\% \\
\hline Valid & Yes & 71 & 89 \\
\cline { 2 - 4 } & No & 5 & 6 \\
\cline { 2 - 4 } & $\begin{array}{l}\text { I don`t } \\
\text { know }\end{array}$ & 4 & 5 \\
\cline { 2 - 4 } & Total & 80 & 100.0 \\
\hline
\end{tabular}

Thus, at question 1 „Do you think working is important to any person regardless of ethnicity, gender, age, religion, nationality and sexual orientation?" 71 of the subjects responded in the affirmative, with 5 of the subjects responding negatively and only 4 of the subjects responded with „I don't know”. As a percentage, $89 \%$ chose option a) Yes, $6 \%$ chose option b) No and only $5 \%$ chose option c) I don`t know. 
Table no. 5. Frequency of occurrence of subjects' responses to item 2

\begin{tabular}{|l|l|c|c|}
\hline \multirow{4}{*}{ Valid } & Not much & Frequency & Percent $\%$ \\
\cline { 2 - 4 } & Little & 7 & 9 \\
\cline { 2 - 4 } & Somewhat much & 29 & 12 \\
\cline { 2 - 4 } & A great deal & 32 & 40 \\
\cline { 2 - 4 } & Total & 80 & 100.0 \\
\hline
\end{tabular}

Most of the respondents considered the education of the Roma as a decisive factor in their integration into the society, which is a joyful thing because the education is a decisive factor in the life of any person regardless of ethnicity, gender, age, religion, nationality.

Thus, question 2 , To what extent do you consider Roma education important for a chance of success in society? " 32 of the subjects considered education to a great deal, with 29 of the subjects considered it significant to somewhat much, with 12 of the subjects considered it to be significant little and only 7 considered education to be not much important. As a percentage, $40 \%$ chose option d) a greal deal, $36 \%$ chose option c) somewhat much, $15 \%$ chose option b) not much and only $9 \%$ chose option a) little.

Table no. 6. Frequency of occurrence of subjects' responses to item 3

\begin{tabular}{|l|l|c|c|}
\hline \multirow{4}{*}{ Valid } & & Frequency & Percent $\%$ \\
\cline { 2 - 4 } & Yes & 28 & 35 \\
\cline { 2 - 4 } & No & 43 & 54 \\
\cline { 2 - 4 } $\begin{array}{l}\text { I don`t } \\
\text { know }\end{array}$ & 9 & 11 \\
\cline { 2 - 4 } & Total & 80 & 100.0 \\
\hline
\end{tabular}

On the third item „Do you think we are equal in terms of employment opportunities regardless of ethnicity?" 43 of the subjects considered that we are not equal before the chances of employment, 28 of the subjects considered that we were equal and only 9 of the subjects said that they did not know whether or not we are equal before the chances of employment regardless of ethnicity.

As a percentage, those who responded with b) No, 54\%, followed by those who responded with a) Yes, 35\% and finally those who chose c) I do not know, in 11\% percent.

Table no. 7. Frequency of occurrence of subjects' responses in item 4

\begin{tabular}{|l|l|c|c|}
\hline \multirow{3}{*}{ Valid } & & Frequency & Percent $\%$ \\
\cline { 2 - 4 } & Yes & 71 & 89 \\
\cline { 2 - 4 } & No & 9 & 11 \\
\cline { 2 - 4 } & Total & 80 & 100.0 \\
\hline
\end{tabular}

Regarding the lack of qualification of Roma, the majority of respondents chose in response to question 4 ,Do you think that the lack of qualification of Roma does not allow them access to the labour market? " option a) Yes, they are in the number of 71 people, the remaining 9 respondents choosing option b) No. As a percentage, $89 \%$ of subjects responded in the affirmatively, while $11 \%$ responded negatively. 
Table no. 8. Frequency of occurrence of subjects' responses to item 5

\begin{tabular}{|l|l|c|c|}
\hline & & Frequency & Percent \% \\
\hline Valid & Yes & 7 & 9 \\
\cline { 2 - 4 } & No & 73 & 91 \\
\cline { 2 - 4 } & Total & 80 & 100.0 \\
\hline
\end{tabular}

On the fifth item „, Do you think Roma should only perform certain trades?” 73 of the subjects answered in the negative, while 7 of the subjects answered in the affirmative. 91\% have chosen the option b) No, and $9 \%$ have chosen the option a) Yes.

Table no. 9. The frequency of occurrence of subjects' responses to item 6

\begin{tabular}{|c|c|c|c|}
\hline \multirow{3}{*}{ Valid } & & Frequency & Percent $\%$ \\
\cline { 2 - 4 } & Yes & 52 & 65 \\
\cline { 2 - 4 } & No & 28 & 35 \\
\cline { 2 - 4 } & Total & 80 & 100.0 \\
\hline
\end{tabular}

On the sixth item „Do you consider it necessary to sanction employers who refuse to employ Roma on ethnic grounds?" the vast majority of the respondents replied that they agree with the sanction of such employers, which can be considered a plus point regarding the integration of Roma in the labor market. Thus, 52 of the respondents answered in the affirmative as opposed to the 28 respondents who answered negative.

As a percentage, $65 \%$ chose the answer a) Yes, and $35 \%$ chose the answer b) No.

Table no. 10. The frequency of occurrence of subjects' responses in item 7

\begin{tabular}{|c|c|c|c|}
\hline & & Frequency & Percent \% \\
\hline Valid & Yes & 71 & 89 \\
\cline { 2 - 4 } & No & 9 & 11 \\
\cline { 2 - 4 } & Total & 80 & 100.0 \\
\hline
\end{tabular}

Regarding the right of Roma people to advance on a professional scale according to their competences, it is surprising that the answers given by the respondents are in their favor, as to the question ,Do you think Roma have the right to advance the professional ladder if they have the necessary competence?" the majority answers were affirmative, of 71 , as opposed to the negative ones, which were 9 . As a percentage, $89 \%$ chose as a option a) Yes, and $11 \%$ chose as the answer option b) No.

Table no. 11. The frequency of occurrence of subjects' responses to item 8.1

\begin{tabular}{|l|l|c|c|}
\hline & & Frequency & Percent \% \\
\hline \multirow{4}{*}{ Valid } & Completely disagree & 49 & 61 \\
\cline { 2 - 4 } & Slightly disagree & 18 & 23 \\
\cline { 2 - 4 } & Slightly agree & 9 & 11 \\
\cline { 2 - 4 } & Completely agree & 4 & 5 \\
\cline { 2 - 4 } & Total & 80 & 100.0 \\
\hline
\end{tabular}


On item eight „To what extent do you agree with the following statements?" respondents' responses were varied as they had to choose a response option for each of the 5 statements.

Thus, for the first statement "Roma should benefit from more social aid" 49 of the respondents chose „Completely disagree”, 18 of the respondents chose „Slightly disagree”, 9 of the respondents chose „Slightly agree” and only 4 of them chose „Completely agree”.

As a percentage, $61 \%$ chose option a) Completely disagree, $23 \%$ chose option b) Slightly disagree, $11 \%$ chose option c) Slightly agree and 5\% chose option d) Completely agree.

Table no. 12. The frequency of occurrence of subjects' responses to item 8.2

\begin{tabular}{|l|l|c|c|}
\hline \multirow{4}{*}{ Valid } & & Frequency & Percent \% \\
\cline { 2 - 4 } & Completely disagree & 50 & 62 \\
\cline { 2 - 4 } & Slightly disagree & 18 & 23 \\
\cline { 2 - 4 } & Slightly agree & 7 & 9 \\
\cline { 2 - 4 } & Completely agree & 5 & 6 \\
\cline { 2 - 4 } & Total & 80 & 100.0 \\
\hline
\end{tabular}

For the second statement „Roma have no place in the labor market” 50 of the respondents chose the answer „Completely disagree”, 18 of the respondents chose the answer „Slightly disagree”, 7 of respondents chose the answer „Slightly agree” and only 5 of them chose „Completely agree”.

As a percentage, $62 \%$ chose option a) Completely disagree, $23 \%$ chose option b) Slightly disagree, $9 \%$ chose option c) Slightly agree and $6 \%$ chose variant d) Completely agree.

Table no. 13. The frequency of occurrence of subjects' responses to item 8.3

\begin{tabular}{|l|l|c|c|}
\hline \multirow{3}{*}{ Valid } & Completely disagree & 25 & 25 \\
\cline { 2 - 4 } & Slightly disagree & 32 & 32 \\
\cline { 2 - 4 } & Slightly agree & 19 & 19 \\
\cline { 2 - 4 } & Completely agree & 24 & 24 \\
\cline { 2 - 4 } & Total & 80 & 100.0 \\
\hline
\end{tabular}

For the third statement „Roma are lazy” 25 of the respondents chose „Completely disagree”, 32 of the respondents chose "Slightly disagree”, 19 of the respondents chose „Slightly agree” and 24 of the respondents they chose „Completely agree”.

As a percentage, $25 \%$ chose option a) Completely disagree, $32 \%$ chose option b) Slightly disagree, $19 \%$ chose option c) Slightly agree and $24 \%$ chose option d) Completely agree. 
Table no. 14. The frequency of occurrence of subjects' responses to item 8.4

\begin{tabular}{|l|l|c|c|}
\hline \multirow{3}{*}{ Valid } & & Frequency & Percent $\%$ \\
\cline { 2 - 4 } & Completely disagree & 4 & 5 \\
\cline { 2 - 4 } & Slightly disagree & 5 & 6 \\
\cline { 2 - 4 } & Slightly agree & 10 & 13 \\
\cline { 2 - 4 } & Completely agree & 61 & 76 \\
\cline { 2 - 4 } & Total & 80 & 100.0 \\
\hline
\end{tabular}

For the fourth statement „Roma should work just like everyone else” 61 of the respondents chose „Completely agree”, 10 of the respondents chose „Slightly agree”, 5 of the respondents chose the answer "Slightly disagree" and only 4 of them chose „Completely disagree".

As a percentage, $5 \%$ chose option a) Completely disagree, $6 \%$ chose option b) Slightly disagree, $13 \%$ chose option c) Slightly agree and $76 \%$ chose option d) Completely agree.

Table no. 15. The frequency of occurrence of subjects' responses to item 8.5

\begin{tabular}{|l|l|c|c|}
\hline \multirow{4}{*}{ Valid } & & Frequency & Percent \% \\
\cline { 2 - 4 } & Completely disagree & 20 & 25 \\
\cline { 2 - 4 } & Slightly disagree & 21 & 26 \\
\cline { 2 - 4 } & Slightly agree & 17 & 21 \\
\cline { 2 - 4 } & Completely agree & 22 & 28 \\
\cline { 2 - 4 } & Total & 80 & 100.0 \\
\hline
\end{tabular}

For the fifth statement and the last ,,Roma know only to steal” most subjects replied that they „Completely agree” with this claim, the majority being represented by 22 of the subjects. At odds with them are those who chose „Slightly disagree” as their response option, with 21 subjects. The remaining 37 subjects are divided into the 20 of the respondents who chose „Completely disagree” and the 17 who chose „Slightly agree”.

As a percentage, $25 \%$ chose option a) Completely disagree, $26 \%$ chose option b) Slightly disagree, $21 \%$ chose option c) Slightly agree and $28 \%$ chose option d) Completely agree.

Table no. 16. The frequency of occurrence of subjects' responses to item 9

\begin{tabular}{|l|l|c|c|}
\hline \multirow{2}{*}{ Valid } & & Frequency & Percent \% \\
\cline { 2 - 4 } & Yes & 54 & 67 \\
\cline { 2 - 4 } & No & 26 & 33 \\
\cline { 2 - 4 } & Total & 80 & 100.0 \\
\hline
\end{tabular}

On the nineth item ,Do you think that the integration of the Roma in the labor market would positively influence the economy of the country?" 54 of the subjects considered that the integration of the Roma in the labor market would benefit the economy of the country while 26 of the subjects answered negative. option b) No.

As a percentage, $67 \%$ chose as the answer option a) Yes, and $33 \%$ chose as the answer 
SOCIAL SCIENCES JOURNAL

www.techniumscience.com

Table no 17. The frequency of occurrence of subjects' responses to item 10

\begin{tabular}{|l|l|c|c|}
\hline \multirow{5}{*}{ Valid } & & Frequency & Percent \% \\
\cline { 2 - 4 } & Romanian state & 30 & 37 \\
\cline { 2 - 4 } & $\begin{array}{l}\text { Roma } \\
\text { population }\end{array}$ & 34 & 42 \\
\cline { 2 - 4 } & Ourselves & 10 & 13 \\
\cline { 2 - 4 } & I don`t know & 6 & 8 \\
\cline { 2 - 4 } & Total & 80 & 100.0 \\
\hline
\end{tabular}

On the tenth item ,, Who do you think is guilty for the situation of the Roma community?" The vast majority of the respondents (34 of them) consider the Roma guilty of their own fate, 30 of the respondents consider the state guilty, 10 of the respondents consider that ourselves are guilty of the situation in which the Roma community is and only 6 of the respondents replied that they don't know who is guilty.

As a percentage, $37 \%$ chose as the answer option a) the Romanian state, $42 \%$ chose as the answer option b) the Roma population, 13\% chose as the answer option c) ourselves and only $8 \%$ chose as the answer option d) I don`t know.

Table no. 18. The frequency of occurrence of subjects' responses to item 11

\begin{tabular}{|l|l|c|c|}
\hline & & Frequency & Percent \% \\
\hline Valid & Yes & 56 & 70 \\
\cline { 2 - 4 } & No & 24 & 30 \\
\cline { 2 - 4 } & Total & 80 & 100.0 \\
\hline
\end{tabular}

At the eleventh item „,Do you consider discrimination a barrier to Roma integration in the labor market?" 56 of the respondents answered in the affirmative, while 24 of the subjects answered in the negative. As a percentage, $70 \%$ chose as an answer a) Yes, and $30 \%$ chose as an answer b) No.

Table no. 19. The frequency of occurrence of subjects' responses to item 12

\begin{tabular}{|l|l|c|c|}
\hline \multirow{4}{*}{ Valid } & & Frequency & Percent \% \\
\cline { 2 - 4 } & Yes & 46 & 57 \\
\cline { 2 - 4 } & No & 16 & 20 \\
\cline { 2 - 4 } & $\begin{array}{l}\text { I don`t } \\
\text { know }\end{array}$ & 18 & 23 \\
\cline { 2 - 4 } & Total & 80 & 100.0 \\
\hline
\end{tabular}

On item twelve „Do you think a change in the mentality of the Roma would help them integrate more easily?" 46 of the subjects chose as the answer option a) Yes, 16 of the subjects chose as the answer option b) No and 18 of the subjects chose as the answer option c) I do not know.

As a percentage, $57 \%$ of the subjects answered yes, $20 \%$ answered negative and $23 \%$ chose option c) I do not know. 
Table no. 20. The frequency of occurrence of subjects' responses to item 13

\begin{tabular}{|l|l|c|c|}
\hline & & Frequency & Percent \% \\
\hline \multirow{4}{*}{ Valid } & Yes & 43 & 53 \\
\cline { 2 - 4 } & No & 19 & 24 \\
\cline { 2 - 4 } & $\begin{array}{l}\text { I don`t } \\
\text { know }\end{array}$ & 18 & 23 \\
\cline { 2 - 4 } & Total & 80 & 100.0 \\
\hline
\end{tabular}

At the thirteenth item and the last „If you were an employer would you hire Roma people?” It was found that although the Roma population „enjoys” a high degree of discrimination, the respondents' answers showed that ethnicity is not a decisive factor in the labor market, as 43 of them stated that they would employ Roma people.

The number of those who would not hire Roma people is relatively small, ie 19 and the number of those who chose as an answer option c) I don `t know is 18 respondents.

As a percentage, 53\% of the subjects answered yes, 24\% answered negative and 23\% chose option c) I don`t know.

\section{Conclusions}

Constantly pursued by the status of slaves they were in until February 20th, 1856, classified as lazy, thieves or the plight of society, the Roma continued to be in the same vicious circle of discrimination, lack of understanding, disrespect and interest in their situation, also struggled in the same poverty from which only few managed to get out, poverty that led to a lack of school education, their lack of labour market, the increase in crime and not least to more discrimination.

As a result of the research presented through this work, several conclusions could be drawn from both theorertic and practical.

As for the theoretical part we could start by pointing out that the terminology used by this minority to self-identify has no connection with Romania, the term „Roma” being an old word of the Rromani language and translating ad litteram with „human” or „man”.

It can also be noted that although the Roma currently have big problems in terms of access to the labour market, from the first documentary attestation, namely 1381 to the present day, the Roma have provided different trades.

However, we cannot say that time has been on the side of this population, since as the years passed, the world has changed, new trades have emerged that required prior training, a certain degree of schooling, effectively a certain professional qualification of which Roma cannot say that they were happy.

As can be seen from the research presented in Chapter 2 and 3, the Roma population has been hit by the term „exclusion” either socially or on the labor market.

Low degree of schooling, presence in schools of a very small number of ethnic Roma, high degree of illiteracy as well as school dropouts, lack of professional qualification, lack of identity documents, informal exclusion from assistance services unemployment, opting for undeclared work low mobility and especially discrimination are factors leading to both social exclusion and especially from the labour market of the Roma population.

Although, over the years there have been various policies, projects and programmes on improving the roma situation, the results were not expected, as the real achievement of such improvements had to be based exclusively on an effective implementation of these policies, which implies the involvement of all relevant stakeholders, political support and the allocation of resources needed at the appropriate levels of decision-making. 

Roma" have been achieved, this is not sufficient as a large part of the problems remain unresolved. The implementation of the Strategy remains at a very low level due, in large part, to the insufficient resources or even their lack. The slow pace in which this strategy was carried out has caused dissatisfaction among the Roma population, increasing the distrust of completing this project. Due to these weak achievements, the Romanian Government is developing a new project on the Strategy for improving the situation of the Roma for the period $2011-2020$.

In conclusion, the crucial moment we are in is committed to adopting a coherent package of actions aimed at solving the problems that the Roma population faces, to finally accept the Roma problem in all aspects, considering that the social and economic argument against inaction is too powerful to be avoided.

Regarding the practical part, as a result of the answers given by the respondents we can draw as conclusions that, work has a special importance for any person, regardless of ethnicity, that any Roma person is not reserved only a particular profession and also that, either other person has the right to be present on the labour market, the majority population is also aware of the importance of Roma education for a chance of success in society, through education they are gaining a qualification professional development and why not even the right to advance on professional scarability according to the competences they hold.

In terms of equality in the face of employment opportunities, according to the responses given by the respondents it can be found that the balance tends to tilt towards ,no, we are not equal", but the vast majority of respondents agree to sanction those who refuse to accept the employment of Roma on ethnic grounds, resisting this equal opportunities.

Curious, however, is the contradiction between the fact that the majority of respondents consider Roma lazy and thieves and the fact that, they agree that they should work like all others, that Roma integration into the labour market would benefit the hard economy, and especially since most subjects said they would employ Roma people, a contradiction that it can lead us to the conclusion that a change in Roma mentality is necessary and beneficial for both them as ethnicity and for us as a majority population.

Regarding the situation of the Roma community, as a result of the answers given by the respondents, we can conclude that the Roma are victims of their own mentalities, bearing the consequences of their own decisions, but the Romanian state has an equally great fault.

As a result of the conclusions drawn from both theorertic and practical, we can also say and even emphasize one thing, namely that for a European Romania it would be time for Roma to be freed from the slavery of discrimination and indifference, to acquire the same rights but also obligations as any of the citizens of this state, and not least would be the time to take responsibility for this ethnicity and to take effective action on all levels, economic, social, cultural or political.

\section{References}

[1] Antoniu, G., Proposal National Journal: „Gypsy” instead of „Roma”, March 2nd 2009. http://www.jurnalul.ro

[2] Barometer of Social Inclusion 2010 - Project co-financed from the European Social Fund through the Sectoral Operational Program for Human Resources Development 2007 - 2013 Invest in people!

[3] Bădescu, G., Vlad Grigoraş, Cosima Rughiniş, Mălina Voicu, Ovidiu Voicu, Barometer of Roma Inclusion, Foundation for an Open Society (FSD), 2007, p. 33.

[4] Berevoescu, I., Sorin Cace; Dana Sima Costin; Simona Ilie; Ioan Mărginean; Dan Adrian Nicolae; Marian Preda, Mihai Surdu; Monica şerban, Mălina Voicu; Cătălin 
Zamfir, INDICATORS CONCERNING ROMA COMMUNITIES IN ROMANIA, Volume prepared by the Institute for Quality of Life Research, Bucharest, 2002.

[5] Cace, S., Andrei Constantin, Marcel Dediu, Elena Macioi, Irinel Marius Ştefan, Access of Roma to Social Services - Realities and trends in 2005 -, Foundation for an Open Society, Bucharest, 2006

[6] Cace, S., Daniela Arpinte, Ana Bleahu, Vasile Cantarji, Roma access to the labor market - aspirations, factors and success strategies, Expert Publishing House, Bucharest, 2007.

[7] Donald, K., Roma: from India to the Mediterranean, Col. Interface, Gypsies Research Center - Paris, Alternative Publishing House, Bucharest, 1997, p. 27;

[8] Duminica, G., „Occupation”, Presentation ppt., Sinaia, December 12th - 14th, 2006.

[9] Fleck, G., Cosima Rughiniş, Come closer, Human Dynamics Publishing House, Bucharest, 2008, p.145.

[10] Gelu Duminică, Marian Preda, The access of the Roma to the Labor Market, The Book of Agribusiness Publishing House, Bucharest, 2003, p. 28

[11] Grigore, D., „Roma or Gypsy?”, In Romanothan, March 2009. http://www.romanothan.ro/rom-sau-tigan/De-ce-rrom-si-nu-tigan.htm

[12] Liégeois, J.P., Roma in Europe, the Official Monitor, Bucharest, cop. 2008, p. 9;

[13] Micu, J. Ethnosphere Magazine, Issue 1, July 2008, http://www.cespe.ro/images/macheta1.pdf

[14] Pop, M.L., Dictionary of Social Policies, Bucharest, 2002, p.328.

[15] Tănăsescu, F., DOCTRINES AND POLITICAL INSTITUTIONS, 4th Edition, Romanian Foundation Publishing House of Tomorrow, Bucharest, 2006

[16] Zamfir, C., Preda, M., Roma In Romania, Expert Publishing House, Bucharest, 2002

\section{Internet web sites}

[17] Resource Centre for ethnocultural diversity - a necessary change of strategy - Report on the state of application of the Government Strategy to improve the situation of Roma in Romania, June 2004;

[18] http://www.brandsocial.ro/doc/raport $\% 20$ economie $\% 20$ sociala $\% 20$ sectiunea $\% 201 . p$ df

[19] http://www.evz.ro/detalii/stiri/piata-muncii-ramane-blocata-pentru-romi-

[20] Janina Micu, Ethnosphere Magazine, Issue 1, July 2008, http://www.cespe.ro/images/macheta1.pdf

[21] Resources and cultural consumption in Roma communities: A Pilot Study in Ilfov County, apub

[22] http://portal.unesco.org/culture/en/ev.phpURL ID=35418\&URL DO=DO TOPIC\& URL_SECTION=201.html

[23] http://www.romadecade.org/files/downloads/Decade\%20Watch\%202010/Decade\%2 0Watch\%20Romania\%20Report\%202010\%20RO.pdf 